UDC 631.37

\title{
STUDYING THE CONDITIONS OF ASSEMBLING TRACTION-DRIVE SOIL-PROCESSING AGGREGATES WITH TRACTORS OF TRACTION-ENERGY CONCEPT
}

\author{
V. V. Adamchuk ${ }^{1}$, V. M. Bulgakov ${ }^{2}$, I. V. Holovach ${ }^{2}$, V. P. Kuvachov ${ }^{3}$ \\ ${ }^{1}$ National Scientific Center "Institute for Agricultural Engineering and Electrification of Agriculture" \\ 11, Vokzalna Str, vil. Hlevakha-1, Vasylkivsky District, Kyiv Region, Ukraine, 08631 \\ ${ }^{2}$ National University of Life and Environmental Sciences of Ukraine \\ 15, Heroyiv Oborony Str., Kyiv, Ukraine, 03041 \\ ${ }^{3}$ Tavria State Agrotechnological University
}

18, B. Khmelnytskoho prov., Melitopol, Zaporizhzhia Region, Ukraine, 72310

e-mail:nnc-imesg@ukr.net,vbulgakov@meta.ua,kuvachoff@ukr.net

Received on February 11, 2018

\begin{abstract}
At present the appearance of novel energy-saturated tractors of traction-energy concept requires not only new principles of their aggregating but also the method of assembling aggregates on their basis. Aim. To increase the efficiency of assembling soil-processing aggregates with traction and drive working units based on energysaturated tractors of traction-energy concept. Methods. The study involved the use of the methods of tractor theory, use of machines, field experimental investigations, statistical methods of processing study results, as well as methods of composing programs and numerical computations on PC. Results. The method of assembling soil-processing aggregates with traction and drive working units was suggested on the basis of technical information, available for a wide audience of specialists. Conclusions. The problem of assembling soil-processing aggregates with traction and drive working units on the basis of energy-saturated tractors of tractorenergy concept should be solved with the consideration of the suggested condition of useful power via traction, determined by the friction properties of a tractor, and the power which the tractor can actually transmit via a power take-off shaft or a hydrosystem.
\end{abstract}

Keywords: energy-saturated tractor, traction-drive aggregate, velocity, power, assembling.

DOI: 10.15407 /agrisp5.02.027

\section{INTRODUCTION}

Modern global agricultural production is characterized by a qualitatively new stage of technical re-equipment. More tractors of traction-energy concept appear at the European and global markets [1,2]. Energy saturation of these tractors has a tendency to increase constantly [3]. At the same time, a share of soil-processing aggregates with traction and drive working units is increasing in agricultural machine-building as well [4]. The rational assembling of such aggregates on the basis of traction-energy concept tractors foresees the application of the effective engine capacity not only on the traction, but also on the active drive of working units or technological equipment.

\footnotetext{
(C) V. V. ADAMCHUK, V. M. BULGAKOV, I. V. HOLOVACH, V. P. KUVACHOV, 2018
}

Therefore, the transfer of tractor energetics to traction-energy concept foresees the use of one, two, and more shafts for power transfer to the drive of active units of the agricultural machinery (Fig. 1), which can transmit up to $90 \%$ of engine capacity $[5,6]$. In its essence, the aggregating tractor of tractor-energy concept is actually a traction-energy means with a differentiated system of power take-off.

As a rule, a soil-processing machine-tractor aggregate, assembled on the basis of an energy-saturated aggregating tractor of traction-energy concept foresees the presence of traction and drive working units of agricultural machines or other technological equipment (Fig. 1). In the mentioned aggregates, a tractor is not only a towing agent, but also a source of energy for agricultural machines, aggregated with it, which 


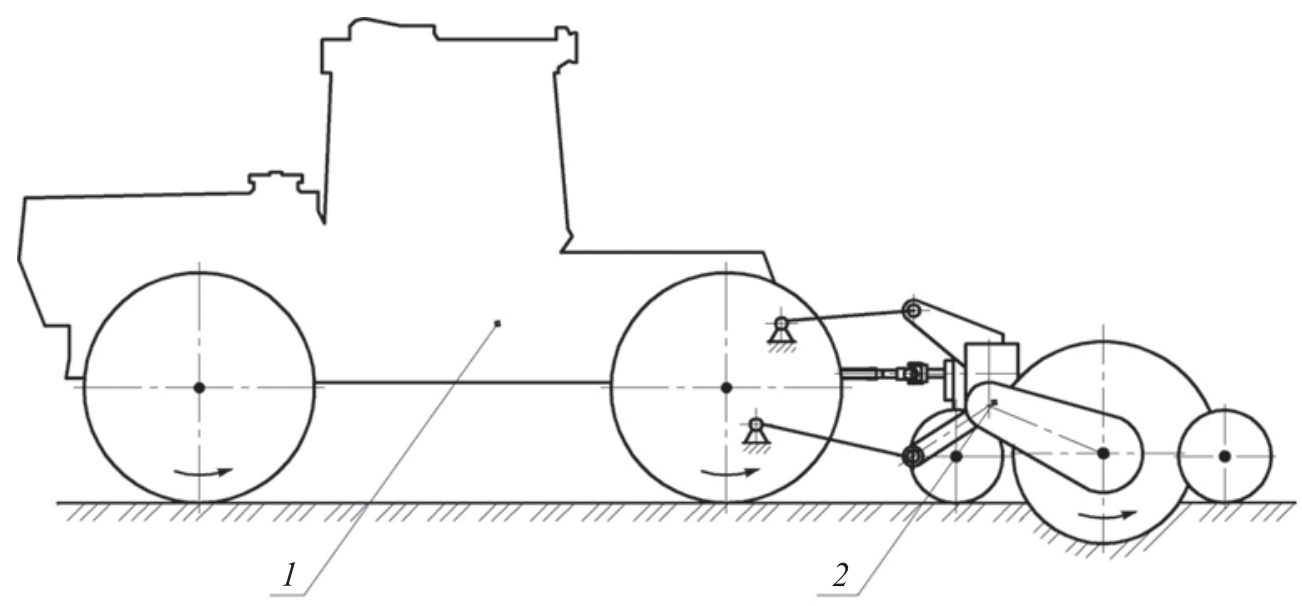

Fig. 1. A tractor-drive soil-processing machine-tractor aggregate: 1 - energy-saturated tractor of traction-energy concept; 2 agricultural vehicle with traction and drive working units

allows solving the problem of efficient use of its engine capacity.

At present the appearance of novel energy-saturated tractors of traction-energy concept requires not only new principles of their aggregating but also the method of assembling aggregates on their basis, as it is currently problematic to use traditional methods while assembling soil-processing aggregates with traction and drive working units from a power take-off shaft or a hydrosystem of energy-saturated tractor [7, 8].

The reason of this problem lies in the fact that according to current classic methods of estimating the composition of aggregates with traction of working units from the power take-off shaft of the tractor, the limiting span of the aggregate is not taken into consideration. It is believed that their composition is conditioned by constructive possibilities of the drive from the power take-off shaft and working conditions. As a rule, traction resistance of a machine is calculated with the determination of traction resistance which is equal in its amount to the traction effort which a tractor could additionally develop due to the power, spent via the power take-off shaft [9].

In this respect, the use of traction characteristics of tractors is also problematic, the solution of issues of assembling traction-drive soil-processing aggregates requires building the characteristics (theoretical ones) for partial take-off of engine capacity of an energy-saturated tractor [10]. But while solving the tasks of assembling soil-processing aggregates with traction and drive working units, the value of power, spent to drive the latter, may be unknown and depends on the span of equipment. As a rule, the latter is subject to substantiation.
At the same time, to build a theoretical traction characteristic of modern tractors according to the classic method, the technical information, provided by plants, manufacturing tractors and agricultural machinery, is usually insufficient for engineering calculations [11].

Due to the abovementioned circumstances, the issue of assembling soil-processing aggregates with traction and drive working units on the basis of energy-saturated tractors becomes urgent nowadays. The availability of a simple method of assembling the rational composition of traction-drive soil-processing aggregates on the basis of energy-saturated tractors will allow maintaining the main principle of their rational assembling, which lies in reasonable selection of excessive engine capacity that is not used. At the end, it will ensure competitive agricultural production with minimal energy expenses for production mechanization processes.

Considering the problems of theory of traction-energy concept tractor, some scientists come to the conclusion that the issues of traction and energy balance require additional investigation [12].

While estimating the impact of the power [5], spent for the drive of active working units of agricultural machines, on the power balance and the coefficient of efficiency of the tractor aggregate, its value is considered to be known (exogenous). However, in the tasks of selecting a traction-drive agricultural machine for the given tractor via the determination of the rational width of span of the aggregate, the value of the consumed power is unknown.

The monograph [13] presents the most complete explanation for the issues of calculating the power and energy indices of rotational combined soil-processing 


\section{STUDYING THE CONDITIONS OF ASSEMBLING TRACTION-DRIVE SOIL-PROCESSING}

machines. The mentioned work is presented (and this is its obvious value) as a comprehensive study of soilprocessing machines with traction-drive working units. Using the information, presented in the monograph, it is complicated to implement a simple algorithm of selecting the composition and working velocity of the traction-drive aggregate based on current technical information, available for a wide audience of specialists.

The authors of several latest educational textbooks and publications [14-18] suggest a new method of calculations on assembling machine-tractor aggregates based on current technical information with clear sequence of engineering computations. But the mentioned references consider the issues of assembling soil-processing aggregates with traction and drive working units based on energy-saturated tractors of traction-energy concept in a trivial and shallow way. Compared to the main provisions of theoretical and experimental studies of traction-drive combined soil-processing machines, stipulated in [13, 19-21], the method of their assessment and aggregating is very averaged.

In this article we present the method of assembling soil-processing aggregates with traction and drive working units based on energy-saturated tractors of traction-energy concept in a novel way.

The aim of the studies was to increase the efficiency of assembling soil-processing aggregates with traction and drive working units based on energy-saturated tractors of traction-energy concept.

\section{METHODS OF STUDIES}

The study involved the use of the methods of tractor theory, use of machines, field experimental investigations, statistical methods of processing the study results, as well as methods of composing programs and numerical computations on PC.

\section{RESULTS OF STUDIES AND THEIR DISCUSSION}

Assembling any machine-tractor aggregates presupposes the selection of a tractor and agricultural machines, aggregated with it. The assembled aggregates should ensure a required quality of a performed technological operation, maximal performance and minimal consumption of fuel, i.e. minimum energy expenses in specific conditions. The mentioned aim may be achieved when a traction (or complete) coefficient of efficiency of a tractor, working in the structure of the aggregate, is close to the maximally possible one in the given conditions.
Meeting all the mentioned requirements (sometimes contradictory ones) is possible only in case of complex solution for assembling machine-tractor aggregates both at the stage of formation and in the immediate exploitation conditions.

The initial moment in assembling any machine-tractor aggregate is selecting the optimal composition and velocity-wise regime of its work.

The statistical energy balance of the energy-saturated tractor is placed as the basis for the method of assembling soil-processing aggregates with the drive of active working units of agricultural machines from the power take-off shaft $[5,22]$. It is known that in case of stable movement of a tractor along a horizontal part of a field, the balance of power in its composition is as follows:

$$
N_{e}=N_{f}+N_{t r}+N_{\delta}+N_{p l}+N_{P T O}
$$

where $N_{e}$ - efficient tractor engine capacity; $N_{f}, N_{t r}$, $N_{\delta}$ - capacity, which characterizes energy losses for overcoming the rolling resistance of the tractor, friction in transmission and sliding of its movers; $N_{p l}$ - tractive power of the tractor; $N_{P T O}$ - power, transmitted via the power take-off shaft or the hydrosystem of the tractor.

It is known from the theory of the tractor [22] that

$$
\begin{aligned}
& N_{f}=f \cdot G V, \\
& N_{t r}=N_{e}\left(1-\eta_{m}\right), \\
& N_{\delta}=N_{e} \cdot \eta_{m} \cdot \delta,
\end{aligned}
$$

where $G$-weight of the tractor, $\mathrm{kN} ; V$ - working velocity of the aggregate movement, $\mathrm{km} \cdot(\mathrm{h})^{-1} ; \eta_{m}-$ mechanical coefficient of efficiency of tractor transmission; $f$ - coefficient of the rolling resistance of the tractor wheels; $\delta$-coefficient of sliding of the tractor movers.

Let us separate the useful (active) power $\left(N_{a}\right)$ in equation (1) of the energy balance of the energy-saturated tractor which may be realized for the implementation of the technological process in the composition of a machine-tractor aggregate i.e. to overcome the traction resistance of agricultural machines $\left(N_{p l}\right)$ and for the drive of their working units from the power take-off shaft or the hydrosystem $\left(N_{P T O}\right)$ :

$$
N_{a}=N_{e}-N_{f}-N_{t r}-N_{\delta}
$$

Certainly, the power, needed for the work of the aggregate $\left(N_{u n}\right)$, should not exceed $N_{a}\left(N_{a} \geq N_{u n}\right)$.

Taking dependences (1) and (2) into consideration, the equation (3) will look as follows:

$$
N_{a}=N_{e} \cdot \eta_{m} \cdot(1-\delta)-f \cdot G V \geq N_{u n}
$$


ADAMCHUK et al.

The power $N_{u n}$, required for the work of the tractiondrive aggregate in the agrotechnically possible range of movement velocities $\left(V_{\min }, \ldots, V_{\max }\right)$, consists of traction power and power, transmitted via the power take-off shaft of the tractor, i.e.:

$$
N_{u n}=N_{P T O} \pm N_{p l}
$$

here "+" or "--" depends on the direction of the "prompted" reaction of the rotational unit $[12,13]$.

The tractive power $N_{p l}$ of the soil-processing aggregate is calculated pursuant to the following dependence:

$$
N_{p l}=F_{p l} \cdot V,
$$

where $F_{p l}$ - traction resistance of a working machine, the value of which depends on the construction of its active working units.

Let us use the dependence for determining the traction resistance via relative resistance of soil-processing machines for further studies [9]:

$$
F_{p l}=B_{u n} \cdot k_{m}
$$

where $k_{m}$ - relative traction resistance of the agricultural machine, $\mathrm{kN} \cdot \mathrm{m}^{-1}$ :

$$
k_{m}=k_{0}\left[1+\left(V-V_{0}\right) \frac{\Delta c}{100}\right],
$$

where $k_{0}$ - relative traction resistance of the agricultural machine $\left(\mathrm{kN} \cdot \mathrm{m}^{-1}\right)$ at the reference movement velocity $V_{0}=5 \mathrm{~km} \cdot(\mathrm{h})^{-1} ; \Delta c$ - rate of increase in the relative traction resistance, \% [9].

Taking into consideration the dependences (7) and (8), the tractive power $N_{p l}$ of the machine-tractor aggregate will look as follows:

$$
N_{p l}=k_{0}\left[1+\left(V-V_{0}\right) \frac{\Delta c}{100}\right] B_{u n} V .
$$

It is known that the implementation of tractive power in the aggregate is determined by friction properties of the tractor, i.e. it depends on the ability of its movers to transmit the required (reactive) power for the work of the aggregate:

$$
N_{\mu}=F_{\mu} \cdot V,
$$

where $N_{\mu}$ - power, conditioned by the friction properties of the tractor; $F_{\mu}$ - maximal power of friction for the movers of the tractor and soil is determined via the dependence [22]:

$$
F_{\mu}=G \cdot \lambda \cdot \mu,
$$

where $\lambda$ - share of the exploitation weight of the tractor per one mover (for wheel-type tractors the formulas
$4 \mathrm{~K} 4$ and for track-type tractors $\lambda=1$ ); $\mu$-friction coefficient for the tractor movers and soil.

Then, the tractive power $N_{\mu p l}$, conditioned by the friction properties of the tractor, with the consideration of losses for towing and sliding, may be determined by the following dependence:

$$
N_{\mu p l}=N_{\mu}-N_{\delta}-N_{f}
$$

As mentioned above, the tractive power, conditioned by the friction properties of the tractor, should exceed $N_{p l}$. Taking into consideration dependences (2) the equation (12) for the determination of $N_{\mu p l}$ will look as follows:

$$
N_{\mu p l}=G V(\lambda \mu-f)-N_{e} \cdot \eta_{m} \cdot \delta \geq N_{p l} .
$$

The calculation of power loss $N_{\text {PTO }}$ on the active drive of working units of the traction-drive aggregate also depends on the construction of working units of the agricultural machine. It is known from the theory of agricultural machines that the power, spent for work of, for instance, a rotational soil-processing machine, consists of a sum of powers for the processing of soil, the creation of "pushing" power and overcoming losses in the machine drive. Here the mentioned components of determining the power on the drive of working units are specified by a number of their constructive-technological and mode parameters, in particular, the width of span and velocity of movement of the unit

$$
N_{\text {PTO }}=f\left(B_{u n} ; V\right)
$$

Taking the abovementioned into consideration, let us assume for further studies that some group of agricultural machines, in which the working units were similar in construction and driven from the power takeoff shaft or the hydrosystem of the tractor, requires the power $N_{P T O}$ to their drive and is in proportion to the relative power per one unit of the width of span of the aggregate and its movement velocity in similar conditions of their use:

$$
N_{\text {PTO }}=k_{P T O} \cdot B_{u n} \cdot V,
$$

where $k_{P T O}$ - relative power, spent for the drive of working units from the power take-off shaft, $\mathrm{kN} \cdot \mathrm{m}^{-1}$.

It should be noted that this approach to determining relative traction resistance of agricultural machinery, in which working units are driven into action from power take-off shaft of the aggregating tractor, is presented in [9].

To substantiate this assumption, let us analyze the experimental dependence for the total power, spent for the work of the rotational plough PR-2.7, on its 


\section{STUDYING THE CONDITIONS OF ASSEMBLING TRACTION-DRIVE SOIL-PROCESSING}

width of span at different velocities of movement (Fig. 2) [13].

According to the information, presented in Fig. 2, due to the calculation of relative power $k_{P T O}$, spent for the drive of working units of the rotational plough PR2.7 , the equation (14) was used to determine that in the range of the mentioned values of the width of span and movement velocity the variability of the estimated value $k_{P T O}$ did not exceed $10 \%$. This result is completely acceptable taking into consideration the accuracy of the obtained experimental data in Fig. 2 and their approximation. Thus, in general, it is reasonable to assume the dependence (14). One should also agree to the fact that the relations between the index $k_{P T O}$ and other parameters, impacting the power expenses on the drive of working units, for instance, by the rate of energy loss gain calculated as per $1 \mathrm{~km} \cdot(\mathrm{h})^{-1}$ of velocity gain, etc., should be proven with arguments. The determination of the index may require the application of more complicated dependences. However, it should be highlighted that this assumption requires scientific substantiation and gives grounds for further studies.

It is clear that power $N_{P T O}$ should not exceed maximally possible power, which the tractor can actually transmit via the power take-off shaft or the hydraulic system $\left[N^{m}{ }_{\text {PTO }}\right]$ :

$$
N_{P T O} \leq N^{m}{ }_{P T O} .
$$

The main criteria of assembling soil-processing aggregates with traction and drive working units based on energy-saturated tractors of traction-energy concept are considered as follows:

- the maximal performance $W$ of the machine-tractor aggregate for $1 \mathrm{~h}$ of "pure" work, ha. $(\mathrm{h})^{-1}$ :

$$
W=0.36 \cdot B_{u n} \cdot V \rightarrow \max ,
$$

- maximal tractive $\eta_{t}$ and complete $\eta$ coefficients of the useful action of the tractor:

$$
\begin{aligned}
& \eta_{t}=\frac{N_{p l}}{N_{e}-N_{P T O}} \rightarrow \max , \\
& \eta=\frac{N_{p l}+N_{P T O}}{N_{e}} \rightarrow \max ,
\end{aligned}
$$

- minimal (relative) fuel expenses per unit of conducted work $q, \mathrm{~kg} \cdot \mathrm{ha}^{-1}$ :

$$
q=\frac{10^{-3} q_{e} \cdot N_{e}}{W} \rightarrow \min ,
$$

where $q_{e}$ - relative (nominal) fuel expense by the tractor engine, $\mathrm{g} \cdot(\mathrm{kWt} \cdot \mathrm{h})^{-1}$.

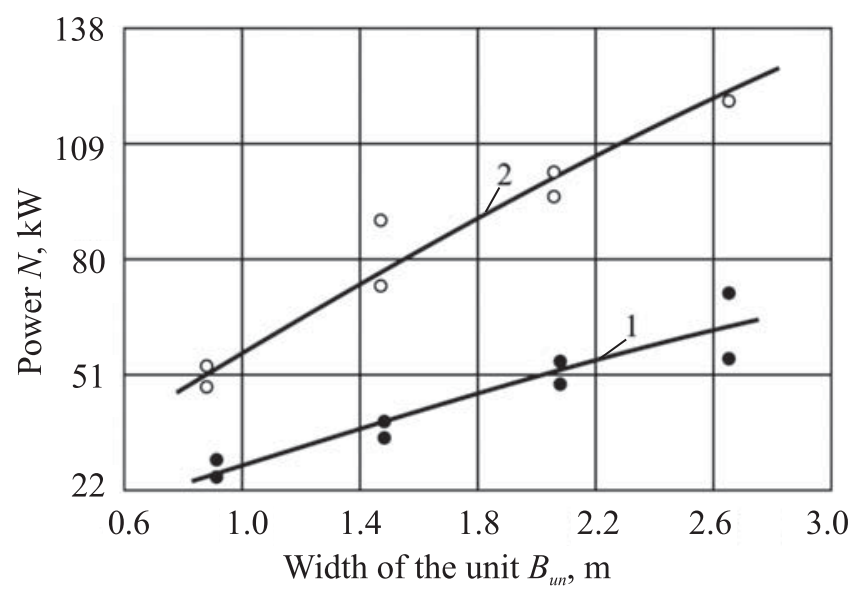

Fig. 2. The dependence of the total spent power $N$ on the width of span $B_{u n}$ of the plough PR-2.7 at the following movement velocities: $1-1.17 \mathrm{~m} \cdot \mathrm{s}^{-1} ; 2-1.95 \mathrm{~m} \cdot \mathrm{s}^{-1}$ [13]

The main parameters of determining the criteria, characterizing the reasonability of assembling the aggregate, is its width of span $B_{u n}$ and the velocity of translation movement $V$.

On uniting equations (4), (5), (9) and (13-19) into a single system, we receive the mathematical model of realization in the aggregate with traction and drive working units of the useful power of the tractor, which will ensure maximal efficiency and minimal fuel expense in actual working conditions:

$$
\begin{aligned}
& N_{a}=N_{e} \cdot \eta_{m}(1-\delta)-f \cdot G V \geqslant N_{u n} ; \\
& N_{\mu p l}=G V(\lambda \mu-f)-N_{e} \cdot \eta_{m} \cdot \delta \geqslant N_{p l} ; \\
& N_{u n}=N_{P T O} \pm N_{p l} ; \\
& N_{p l}=k_{0}\left[1+\left(V-V_{0}\right) \frac{\Delta c}{100}\right] B_{u n} V \\
& N_{P T O}=k_{P T O} \cdot B_{u n} \cdot V \leqslant\left[N^{m}{ }_{P T O}\right] \\
& \mathrm{W}=0.36 B_{u n} V \rightarrow \max ; \\
& \eta_{t}=\frac{N_{p l}}{N_{e}-N_{P T O}} \rightarrow \max ; \\
& \eta=\frac{N_{p l}+N_{P T O}}{N_{e}} \rightarrow \max ; \\
& q=\frac{10^{-3} q_{e} \cdot N_{e}}{W} \rightarrow \min .
\end{aligned}
$$

The task of assembling the machine-tractor aggregate with traction and drive working units depends on the set task.

The method of solving the latter has several approaches:

1) an agricultural machine with traction and energy working units should be selected for the given energysaturated tractor;

2) an aggregating tractor, ensuring the maximal efficiency of the aggregate at minimal energy expenses 
for the implementation of a technological operation should be selected for the given agricultural machine with traction and drive working units;

3 ) in case of known composition of a soil-processing aggregate with traction and drive working units on the basis of an energy-saturated tractor, there should be substantiation of the rational velocity of its movement, according to which the efficient power of tractor engine is used in the most complete way in the given conditions of exploitation.

Solving the tasks of the first approach involves determining such width of span $\mathrm{B}_{u n}$ and velocity of movement $V$ of the aggregate, for which the conditions of the system of equations will be true (20).

Solving the tasks of the second approach, first of all, one should analytically estimate the ranges of minimally required exploitation weight of the tractor $G_{\min }, \ldots$ ,$G_{\max }$ and the efficient power $N_{\text {e } \min }, \ldots, N_{\text {e } \max }$ of its engine in the determined range of agrotechnically possible velocities $V_{\min }, \ldots, V_{\max }$ of the aggregate movement, in which the conditions of the system of equations will be true (20).

Solving the tasks of the third approach comes down to the analytical determination of such rational velocity $V$ of the movement of the machine-tractor aggregate, for which the conditions of the presented system of equations will also be true (20).

To accomplish the set task, we shall assume that all the parameters of tractors and conditions of exploitation, used in the calculations, are weighted mean values. In actual conditions all the values of parameters in some interval are changed according to the stochastic law. In conditions of industrial exploitation, while solving the tasks in rational assembling the machine-tractor aggregates, the averaged parameters of tractors and conditions of their usage are quite acceptable and sufficient [9].

Let us have analytical and subsequent consideration of the abovementioned tasks of assembling the machine-tractor aggregate with traction and drive working units from three previously set tasks.

1) While solving the tasks of the first approach we shall assembly a traction-drive aggregate on the basis of an energy-saturated tractor KhTZ-243K.20 in the composition of a rotational plough (PR type), promising in Ukraine.

Below we present the technical characteristics of such a machine-tractor aggregate and the conditions of its operational research.
Short technical characteristics of KhTZ-243K.20:

Exploitation weight $(G), \mathrm{kN}$

Engine capacity $\left(N_{e}\right), \mathrm{kWt}$

Relative fuel expense $\left(q_{\mathrm{e}}\right)$ by the engine, $\mathrm{g} \cdot(\mathrm{kWt} \cdot \mathrm{h})^{-1}$

Power, which the tractor can transmit via the power take-off shaft $\left[N_{P T O}\right], \mathrm{kWt}$ :

$$
\begin{aligned}
& \text { - at } 540 \mathrm{~min}^{-1} \\
& \text { - at } 1,000 \mathrm{~min}^{-1}
\end{aligned}
$$

Short technical characteristics of rotational ploughs PR [13]:

Relative traction resistance of the plough $\left(k_{0}\right)$,

$\mathrm{kN} \cdot \mathrm{m}^{-1}$

Relative power, spent for the drive of working units from the power take-off shaft, $\left(k_{P T O}\right), \mathrm{kN} \cdot \mathrm{m}^{-1}$

Agrotechnically possible range

of movement velocities $\left(V_{\min }, \ldots, V_{\max }\right), \mathrm{km} \cdot(\mathrm{h})^{-1} 4 \ldots 7$

Aggregate exploitation conditions:

Agricultural background - stubble of grain crops

Rolling resistance coefficient of the tractor

wheels $(f)$

Friction coefficient for tractor movers and

soil $(\mu)$

Permissible coefficient of sliding of

movers $(\delta)$

Solving the system of equations (20) on PC in Mathcad environment allowed obtaining the following results: first and foremost, the rational parameters of the width of span of the aggregate $\mathrm{B}_{u n}=4 \mathrm{~m}$ and the movement velocity $V=4.81 \mathrm{~km} \cdot(\mathrm{h})^{-1}$. Also, we determined graphic dependences of useful power $N_{a}$, tractive power $N_{\mu p l}$ and power, required for the work of the aggregate $N_{u n}^{\mu p}$ on the movement velocity of the aggregate in the composition of rotational ploughs PR-4, PR-2.7 and PR-2, the width of span $\mathrm{B}_{u n}$ of which is 4 , 3 , and $1.8 \mathrm{~m}$ (Fig. 3).

The analysis of graphic dependences in Fig. 3 demonstrates that in the interval of velocities from $V_{\min }$ to $V_{\max }$ the tractive possibilities of the aggregating tractor are limited by its friction properties (friction of movers with soil is insufficient for the realization of the useful power of the engine). A part of useful power of the tractor engine, which is not used completely to overcome tractive resistance of the aggregate, may be transmitted 


\section{STUDYING THE CONDITIONS OF ASSEMBLING TRACTION-DRIVE SOIL-PROCESSING}

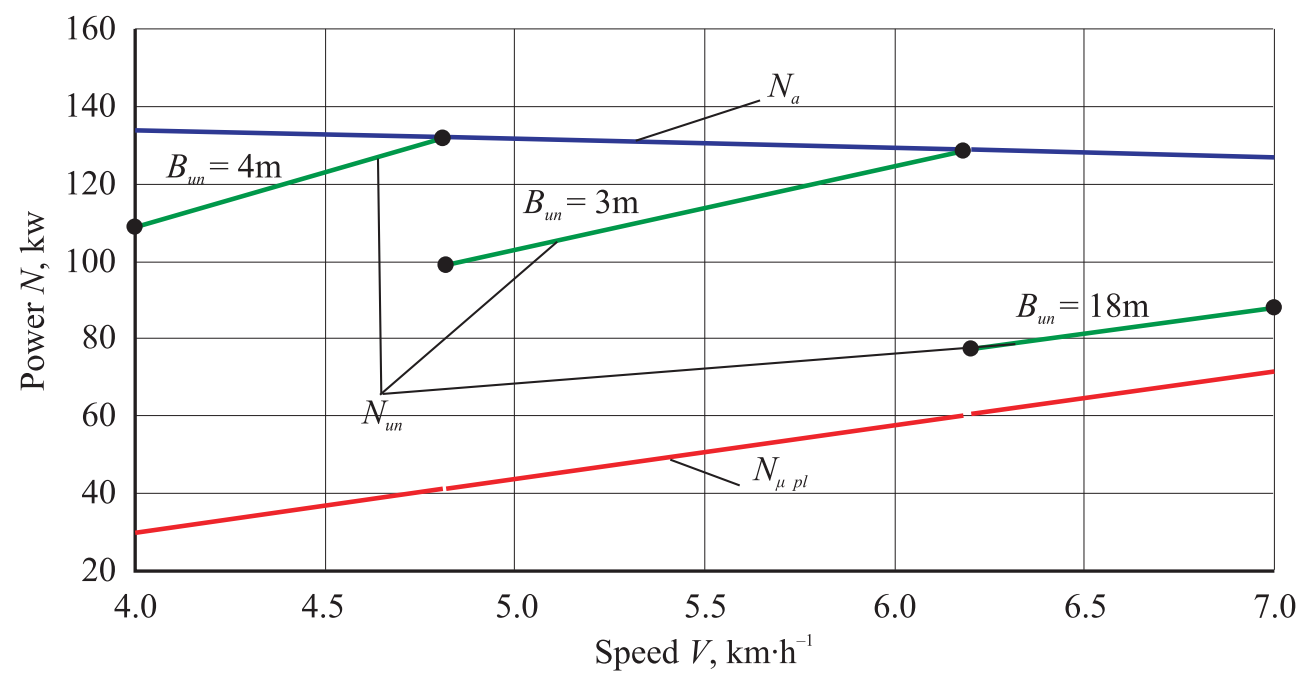

Fig. 3. The dependence of aggregate powers on the velocity of its translation movement (traction-drive aggregate of PR type on the basis of tractor KhTZ-243K.20)

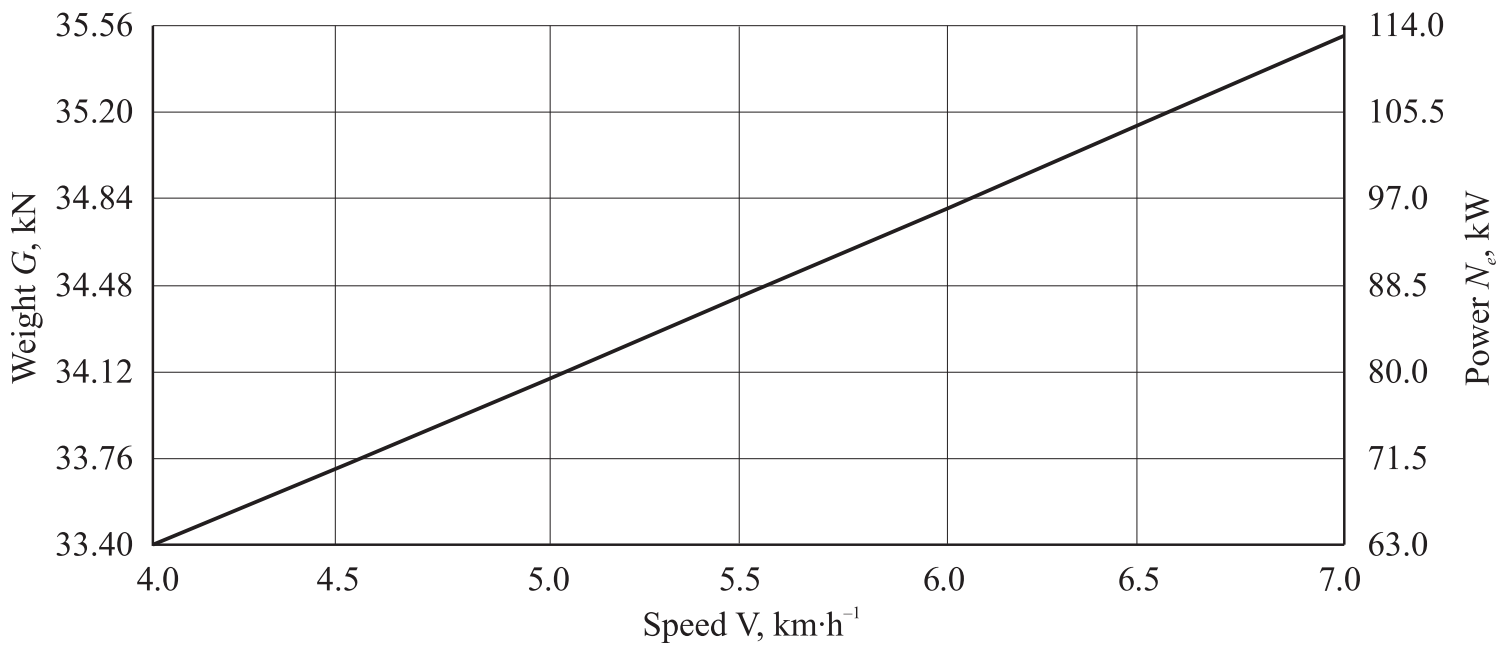

Fig. 4. The dependence of minimally required exploitation weight $G$ of the tractor and the efficient power $N_{e}$ of its engine for aggregating with rotational plough PR-2 at different velocities of its movement

via the power take-off shaft or the hydrosystem of the tractor on the drive of working units of agricultural machines or other technological equipment.

The maximal realization of useful power of the tractor in the aggregate is achieved in two variants of its assembling: at $\mathrm{B}_{u n}=4 \mathrm{~m}$ and $V=4.81 \mathrm{~km} \cdot(\mathrm{h})^{-1}$ and $\mathrm{B}_{u n}=3 \mathrm{~m}$ and $V=6.18 \mathrm{~km} \cdot(\mathrm{h})^{-1}$. However, according to the criteria of maximal productivity, tractive and complete coefficient of useful action of the tractor and minimal fuel expense, the first variant is better. The mentioned parameters for it are $W=1.924 \mathrm{ha} \cdot(\mathrm{h})^{-1}$, $\eta_{t}=0.416, \eta=0.716, q=20.56 \mathrm{~kg} \cdot \mathrm{ha}^{-1}$, contrary to the second variant of the aggregate composition, in which $W=1.854$ ha. $(\mathrm{h})^{-1}, \eta_{t}=0.402, \eta=0.698$, $q=21.33 \mathrm{~kg} \cdot \mathrm{ha}^{-1}$.
2) Solving the tasks of the second approach for the mentioned rotational plough PR-2 with the width of span $B_{u n}=1.8 \mathrm{~m}$, we shall substantiate the required efficient power of the engine and the weight of the tractor, which ensures the maximal performance of the aggregate at minimal energy expenses for the implementation of a technological operation. The technical indices of rotational ploughs and the working conditions of the aggregate shall be the same as for the first task.

Solving the system of equations (20) on PC in Mathcad environment allowed determining the ranges of minimal required exploitation weight of the aggregating tractor $33.4 \ldots 33.5 \mathrm{kN}$ and the efficient power $63 \ldots 113 \mathrm{kWt}$ of its engine in the set range of 
ADAMCHUK et al.

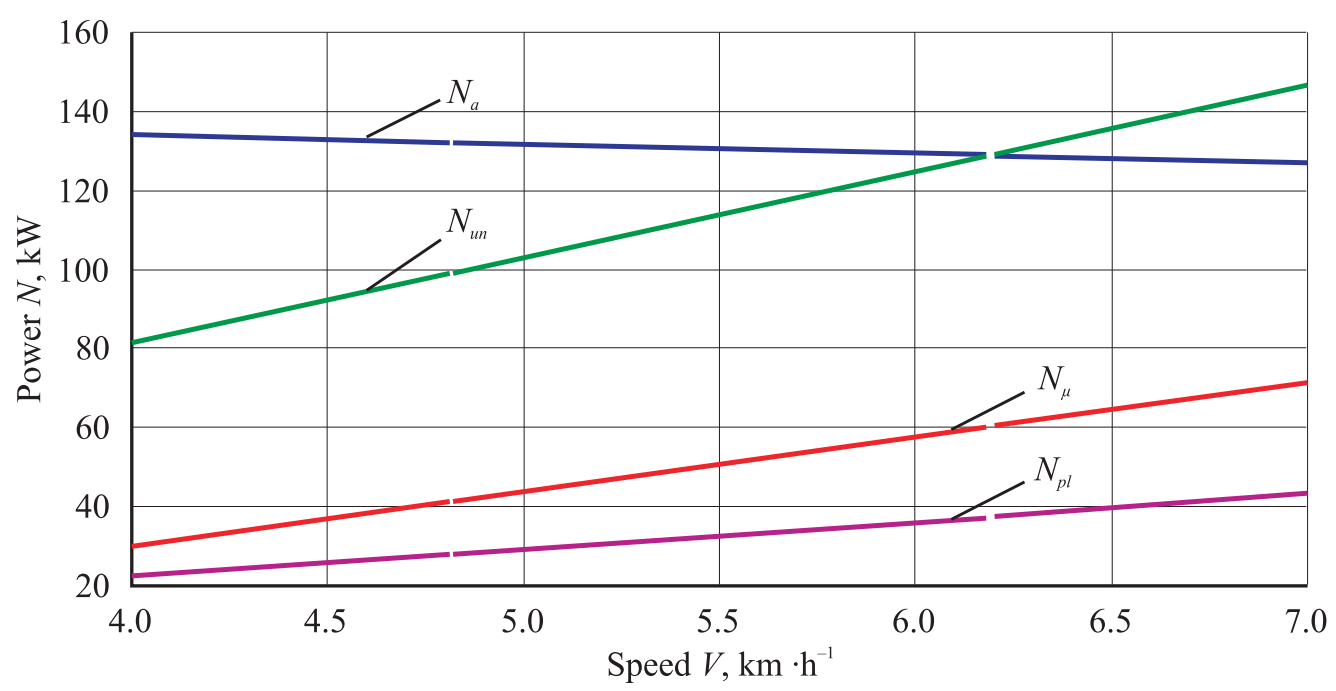

Fig. 5. The dependence of the aggregate power in the structure of tractor KhTZ-243K.20 and plough PR-2.7 on the velocity of its translation movement

agrotechnically possible velocities of the aggregate movement (Fig. 4).

The range of power was also determined as $35.4 \ldots 61.9 \mathrm{kWt}$, spent for the drive of working units of the rotational plough in the interval of agrotechnically possible velocities of its movement.

A required aggregating tractor is selected by the calculated parameters. This may be one of KYI-14102 tractors, or Belarus-1221.2, produced by MTZ-Ukraine Company, the weight of which is $39 \mathrm{kN}$ and $52 \mathrm{kN}$, and the nominal efficient power of engines is $77.2 \mathrm{kWt}$ and $96.0 \mathrm{kWt}$ respectively.

The analysis of the graphic dependence, presented in Fig. 4, indicates that with the increase in the movement velocity of the aggregate, considered in the range from 4.0 to $7.0 \mathrm{~km} \cdot(\mathrm{h})^{-1}$, the intensity of increasing the required exploitation weight $G$ of the tractor and efficient power $N_{\rho}$ of its engine is different. It is known that the ratio of the mentioned parameters determines the required level of the energy saturation of the tractor. In the mentioned interval of movement velocity, the required level of energy saturation of the tractor $N_{e} \cdot G^{-1}$ changes from 1.89 to $3.18 \mathrm{kWt} \cdot(\mathrm{kN})^{-1}$. However, according to the recent forecast of the dynamics of energy saturation of tractors up to 2030 [3], the index of their energy saturation may be only at the level of $2.55 \mathrm{kWt} \cdot(\mathrm{kN})^{-1}$. At this level of energy saturation, the tractor in the structure of the aggregate under study may develop the movement velocity not exceeding 5.5 $\mathrm{km} \cdot(\mathrm{h})^{-1}$ (see Fig. 4).

3) Solving the tasks of the third approach, let us substantiate the rational movement velocity of the traction-drive aggregate in the structure of tractor KhTZ-243K.20 and the rotational plough PR-2.7 with the width of span $B_{u n}=3 \mathrm{~m}$. The technical indices of rotational ploughs and the working conditions of the aggregate shall be the same as for the first task.

Therefore, solving the task of the third approach comes down to determining the rational movement velocity of this aggregate, at which the tractive possibilities of the tractor are used the most in the conditions under consideration.

Solving the system of equations (20) on PC in Mathcad environment with regards to the movement velocity $V$ of the mentioned aggregate demonstrated (Fig. 5) that in the whole interval under consideration the power $N_{\mu p l}$, conditioned by the friction properties of the tractor, exceeded its tractive power $N_{p l}$. And this means that the movers of tractor KhTZ-243K.20 in the mentioned interval of the agrotechnically possible movement velocity are capable of transmitting the required reactive power for the work of the aggregate with the consideration of losses for towing and rolling. Therefore, according to the initial conditions of the task the friction properties of the tractor are sufficient to overcome the traction resistance of plough PR-2.7.

However, if in the movement velocity interval from 4.0 to $6.18 \mathrm{~km} \cdot(\mathrm{h})^{-1}$ the useful power $N_{a}$ of the tractor may be realized by the latter for the work of the mentioned traction-drive aggregate, it is not possible in the interval from 6.18 to $7.0 \mathrm{~km} \cdot(\mathrm{h})^{-1}$ (see Fig. 5). It is absolutely obvious that the rational velocity of the aggregate movement under consideration may be achieved in case of complete realization of useful power $N_{a}$ by 


\section{STUDYING THE CONDITIONS OF ASSEMBLING TRACTION-DRIVE SOIL-PROCESSING}

the tractor i.e. on condition of equality $N_{a}=N_{u n}$. According to the mentioned equation of power it follows that the rational value of the movement velocity of this aggregate is $6.18 \mathrm{~km} \cdot(\mathrm{h})^{-1}$.

\section{CONCLUSIONS}

The problem of assembling soil-processing aggregates with traction and drive working units on the basis of energy-saturated tractors of tractor-energy concept should be solved with the consideration of the suggested condition of useful power via traction, determined by the friction properties of a tractor, and the power which the tractor can actually transmit via the power take-off shaft or the hydrosystem.

This method may be used to solve tasks of assembling the soil-processing aggregates with traction and drive working units on the basis of technical information, presented in the characteristics of tractors and agricultural machines and common reference literature on the issues of the use of machines in agriculture. The assumption, by which the calculation of power for the drive of working units is made via averaged values of relative power per one unit of the width of span and movement velocity of the aggregate, is subject to further substantiation.

\section{Дослідження умов комплектування тягово-приводних грунтообробних агрегатів з тракторами тягово-енергетичної концепції}

В. В. Адамчук ${ }^{1}$, В. М. Булгаков ${ }^{2}$,

І. В. Головач ${ }^{2}$, В. П. Кувачов ${ }^{3}$

e-mail:nnc-imesg@ukr.net, vbulgakov@meta.ua, kuvachoff@ukr.net

${ }^{1}$ Національний науковий центр “Інститут механізації та електрифікації сільського господарства”

${ }^{2}$ Національний університет біоресурсів і природокористування України

${ }^{3}$ Таврійський державний агротехнологічний університет

Поява абсолютно нових енергонасичених тракторів тягово-енергетичної концепції потребує сьогодні не тільки нових принципів їх агрегатування, a i методики комплектування агрегатів на їх основі. Мета. Підвищення ефективності комплектування грунтообробних агрегатів 3 тяговими і приводними робочими органами на основі енергонасичених тракторів тягово-енергетичної концепції. Методи. При виконанні дослідження використані методи теорії трактора, машиновикористання, польових експериментальних досліджень, статистичні методи обробки результатів досліджень, а також методи складання програм та числових розрахунків на ПК. Результати. Запропоновано методику комплектування грунтообробних агрегатів 3 тяговими і приводними робочими органами на основі технічної інформації, доступної широкому колу фахівців. Висновки. Проблему комплектування грунтообробних агрегатів 3 тяговими і приводними робочими органами на основі енергонасичених тракторів тягово-енергетичної концепції слід розв'язувати 3 урахуванням запропонованої умови реалізації корисної потужності через тягову, визначену зчіпними властивостями трактора, і потужності, яку трактор здатний фактично передати через вал відбору потужності або гідросистему.

Ключові слова: енергонасичений трактор, тягово-приводний агрегат, швидкість, потужність, комплектування.

Исследование условий комплектования тягово-приводных почвообрабатывающих агрегатов с тракторами тягового-энергетической концепции

\section{В. В. Адамчук ${ }^{1}$, В. М. Булгаков ${ }^{2}$,} И. В. Головач ${ }^{2}$, В. П. Кувачов ${ }^{3}$

e-mail:nnc-imesg@ukr.net,vbulgakov@meta.ua, kuvachoff@ukr.net

${ }^{1}$ Национальный научный центр «Институт механизации и электрификации сельского хозяйства»,

${ }^{2}$ Национальный университет биоресурсов и природопользования Украины,

${ }^{3}$ Таврийский государственный агротехнологический университет

Появление совершенно новых энергонасыщенных тракторов тягово-энергетической концепции требует сегодня не только новых принципов их агрегатирования, а и методики комплектования агрегатов на их основе. Цель. Повышение эффективности комплектования почвообрабатывающих агрегатов с тяговыми и приводными рабочими органами на основе энергонасыщенных тракторов тягово-энергетической концепции. Методы. При выполнении исследования использованы методы теории трактора, машиноиспользования, полевых экспериментальных исследований, статистические методы обработки результатов исследований, а также методы составления программ и числовых расчетов на ПК. Результаты. Предложена методика комплектования почвообрабатывающих агрегатов с тяговыми и приводными рабочими органами на основе технической информации, доступной широкому кругу специалистов. Выводы. Проблему комплектования почвообрабатывающих агрегатов с тяговыми и приводными рабочими органами на основе энергонасыщенных тракторов тягово-энергетической концепции следует решать с учетом предложенной условиями реализации полезной мощности через тяговую, определенную сцепными свойствами трактора и мощности, трактор способен фактически передать через вал отбора мощности или гидросистему. 


\section{ADAMCHUK et al.}

Ключевые слова: энергонасыщенный трактор, тяговоприводной агрегат, скорость, мощность, комплектование.

\section{REFERENCES}

1. Tiago de OT, Damasceno AF, Voltarelli MA, Ruverson da PS, Carlos EAF. Effective power and hourly fuel consumption demanded by set tractor-coffee harvester in function of adequacy tractor ballasting. Eng. Agric. 2017;37(4):699-708. doi.org/10.1590/1809-4430-eng. agric.v37n4p699-708/2017.

2. Senthilkumar T, Chandel NS, Mehta CR, Babasahed SG. Trends of Tractorization in Indian Agriculture. AmaAgricultural Mechanization in Asia, Africa and Latin America. 2017;48(2):50-9.

3. Nadykto VT, Velychko OV. Forecasting the development of energy ratio of agricultural tractors. Mechanization and electrification of agriculture. 2015;1(100):147-51.

4. Shepelev $S$, Shepelev V, Almetova Z. Optimization of Technical Equipment for Crop Sowing Processes. Procedia Engineering. 2016;150:1258-62.

5. Adamchuk V, Bulgakov V, Nadykto V, Ihnatiev Y, Olt $J$. Theoretical research into the power and energy performance of agricultural tractors. Agronomy Research. 2016;14(5):1511-8.

6. Roeber JBW, Pitla SK, Hoy RM, Luck JD, Kocher MF. Development and validation of a tractor drawbar force measurement and data acquisition system (DAQ). Applied Engineering in Agriculture. 2017;33(6):781-9. doi.org/10.13031/aea.12489.

7. Thiago MM, Lancas KP, Fiorese DA, Fernandes BB, Testa JVP. Energy expenditure estimate of subsoiling operation at varying depths. Rev. bras. eng. agric. ambient. 2015;19(11):1121-5. doi.org/10.1590/18071929/agriambi.v19n11p1121-1125

8. Park Y-J, Kim S-Ch, Kim J-G. Analysis and verification of power transmission characteristics of the hydro mechanical transmission for agricultural tractors. J. Mechanic. Sci. Technol. 2016;30(11):5063-72. doi: 10.1007/s12206-016-1056-y.

9. Ruzhytsky MA, Riabets VI, Kiashko VM, Burlaka VM, Ivashyna $M B$. Exploitation of machinery and equipment. K.: Ahrarna osvita, 2010:617 p. (in Ukrainian).

10. Shevchenko IO, Pipchenko OM. Specificities of construction and use of theoretical drawbar characteristic of a tractor while selecting power level via GDP. Visnyk KhNTUSH. 2012;124(2):52-60.

11. Lee JW, Kim JS, Kim KU. Computer simulations to maximise fuel efficiency and work performance of agricultural tractors in rotovating and ploughing operations. Biosystems Engineering. 2016;142:1-11. doi.org/10.1016/j.biosystemseng.2015.11.012.

12. Lebedev AT. Some problems of the theory of tractor drawbar-energy concept. Visnyk KhNTUSH. 2012;124(2):5-15.

13. Dzhabborov NI, Dobrinov AV, Semenova GA. Determining energotechnological parameters of dynamic soilprocessing aggregates. Bulletin of Saint-Petersburg State Agrarian University. 2017;(49):252-9.

14. Kuvachev V, Mitkov $V$. Background criteria for opti-mum controlled traffic farming technology complex agricultural units. Scient. bulletin of TDATU. 2012;2(5):8-15. (in Ukrainian).

15. Karabanitsky AP, Ostapchenko VA, Svetlichny PV. Drawbar capacities of modern tractors. Selsky mekhanizator. 2014;(1):6-7.

16. Bulgakov V, Nadykto V, Kaletnik H, Ivanovs S. Field experimental investigations of performance-and-technological indicators of operation of swath header asymmetric machine-and-tractor aggregate. Engineering for rural development, Jelgava, Latvia May 23-25. 2018;17:227-33. doi: 10.22616/ERDev2018.17.N269.

17. Nadykto $V$. Scientific basis of aggregation agricultural machinery. Visnyk KhNTUSH. Technical sciences. 2015; 1(163), 186-94.

18. Dongming G, Lianhao L, Xiaodong Q, Sarker KK. Development and evaluation of power consumption model for no-till planter based on working parameters. Int. J. Agric. Biol. Eng. 2017;10(1):80-7.

19. Lee H-S, Kim J-S; Park Y-I, Cha S-W. Rule-based power distribution in the power train of a parallel hybrid tractor for fuel savings. Int. J. Prec. Eng. Manufacturing-Green Technol. 2016;3(3):231-7. doi: 10.1007/s40684-016003.

20.Bulgakov $V$, Adamchuk $V$, Kuvachov $V$, Ivanovs $S$. Investigation of technological properties of wide span tractors for controlled traffic farming. Engineering for rural development, Jelgava, Latvia May 24-26. 2017;16:303-8. doi: 10.22616/ERDev2017.16.N060.

21. Pitla SK, Luck JD, Werner J, Lin N, Shearer SA. Infield fuel use and load states of agricultural field machinery. Comput. Electron. Agric. 2016;121:290-300. doi:10.1016/j.compag.2015.12.023.

22. Kutkov GM. Tractors and vehicles: theory and technological properties. M.: INFRA-M, 2016:504 p. 